\title{
Bathymetrical distribution and size structure of cold-water coral populations in the Cap de Creus and Lacaze-Duthiers canyons (northwestern Mediterranean)
}

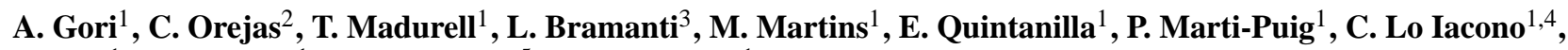 \\ P. Puig ${ }^{1}$, S. Requena ${ }^{1}$, M. Greenacre ${ }^{5}$, and J. M. Gili ${ }^{1}$ \\ ${ }^{1}$ Institut de Ciències del Mar, Consejo Superior de Investigaciones Cientificas, Pg. Marítim de la Barceloneta 37-49, \\ 08003 Barcelona, Spain \\ ${ }^{2}$ Instituto Español de Oceanografía (IEO), Centro Oceanográfico de Baleares, Moll de Ponent s/n, 07015 Palma de Mallorca, \\ Spain \\ ${ }^{3}$ California State University Northridge, 18111 Nordhoff St., Northridge, California 91330, USA \\ ${ }^{4}$ Marine Geosciences, National Oceanography Centre, European Way, Southampton SO14 3ZH, UK \\ ${ }^{5}$ Universitat Pompeu Fabra, Campus de la Ciutadella, C/ Ramon Trias Fargas 25-27, 08005 Barcelona, Spain \\ Correspondence to: A. Gori (gori@icm.csic.es, agori.mail@gmail.com)
}

Received: 29 November 2012 - Published in Biogeosciences Discuss.: 21 December 2012

Revised: 26 February 2013 - Accepted: 27 February 2013 - Published: 25 March 2013

\begin{abstract}
Submarine canyons are known as one of the seafloor morphological features where living cold-water coral (CWC) communities develop in the Mediterranean Sea. We investigated the CWC community of the two westernmost submarine canyons of the Gulf of Lions canyon system: the Cap de Creus Canyon (CCC) and LacazeDuthiers Canyon (LDC). Coral associations have been studied through video material recorded by means of a manned submersible and a remotely operated vehicle. Video transects have been conducted and analyzed in order to obtain information on (1) coral bathymetric distribution and density patterns, (2) size structure of coral populations, and (3) coral colony position with respect to the substrate. Madrepora oculata was the most abundant CWC in both canyons, while Lophelia pertusa and Dendrophyllia cornigera mostly occurred as isolated colonies or in small patches. An important exception was detected in a vertical cliff in LDC where a large $L$. pertusa framework was documented. This is the first record of such an extended $L$. pertusa framework in the Mediterranean Sea. In both canyons coral populations were dominated by medium and large colonies, but the frequent presence of small-sized colonies also indicate active recruitment. The predominant coral orientation $\left(90^{\circ}\right.$ and $\left.135^{\circ}\right)$ is probably driven by the current regime as well as by the sed-
\end{abstract}

iment load transported by the current flows. In general, no clear differences were observed in the abundance and in the size structure of the CWC populations between CCC and LDC, despite large differences in particulate matter between canyons.

\section{Introduction}

Continental margins are the most important areas within the ocean in terms of terrigenous input, biogeochemical cycles and biological production (Walsh, 1991; Valiela, 1995; Levin and Sibuet, 2012). Physical processes occurring at the shelf edge transfer water and particulate matter from the continental shelf to the deep sea (Nittrouer and Wright, 1994), and submarine canyons are the main transport pathways for this transfer (Puig et al., 2003; Palanques et al., 2008; Huvenne et al., 2011). Submarine canyons play a fundamental role in shelf-deep ocean exchanges reducing the time and the distances covered by water masses, and consequently enhancing the transfer of organic and inorganic sediments from shallow to deeper waters (Würtz, 2012). Canyons that extend across the continental shelf and approach the coast intercept and transport down-slope the organic-matter-rich sediments 
transported along the inner shelf zone (Sánchez-Vidal et al., 2009; Lo Iacono et al., 2012). Given such enhancement of trophic resources, canyons may harbour a significantly increased biodiversity and biomass compared to the open slope adjacent areas (Vetter and Dayton, 1998; De Leo et al., 2010; Huvenne et al., 2011).

The continental shelf and slope of the Gulf of Lions, in the northwestern Mediterranean Sea, is one of the areas of the world's oceans with the highest canyon density (Harris and Whiteway, 2011; Würtz, 2012). In the heads of some of these canyons, well developed cold-water coral (CWC) communities have been documented to occur on the rocky bottoms of the canyon flanks (Reyss, 1964a; Orejas et al., 2009; Watremez, 2012). The high structural heterogeneity originating from the growth of CWC provides a complex mosaic of habitats, and promotes the presence of a highly diverse associated fauna (Henry and Roberts, 2007; Buhl-Mortensen et al., 2010) since CWC can act as potential areas of refuge, breeding and feeding for many deep-sea species, including commercially important fish (Husebø et al., 2002; Costello et al., 2005; Ross and Quattrini, 2007; D’Onghia et al., 2010; Baillon et al., 2012).

Occurrence, distribution and abundance of CWC species are strongly influenced by several abiotic factors such as seawater temperature and density, aragonite saturation state, oxygen concentration, presence of appropriate substratum, and water flow regimes (Dullo et al., 2008; Davies et al., 2008; Orejas et al., 2009; Roberts et al., 2009a). Enhanced flows prevent coral smothering by sediments, and play a crucial role in food supply (Roberts et al., 2009b), which has been considered as one of the main governing factors in CWC distribution (Frederiksen et al., 1992; Mortensen et al., 2001; Kenyon et al., 2003; Thiem et al., 2006; Davies et al., 2009). Each canyon presents unique characteristics (Würtz, 2012) with large differences in the sediment fluxes and hydrodynamic features (Palanques et al., 2006; Canals et al., 2009) that make the availability of food to CWC largely variable among canyons. Such differences affect the abundance and species composition of the fauna (Gili et al., 2000), and could result in different suitability and stability of coral habitats, hence inducing differences among their populations. Both the environmental suitability and the stability of a habitat may be reflected in the distribution patterns of coral colonies, as well as in the size structure of coral populations, because the size structure reflects the factors affecting recruitment, growth, and mortality rates in a particular habitat for a period of time equal to the longevity of the population (Grigg, 1975).

In this study, video analysis methods have been employed to compare the state of CWC populations in the Cap de Creus Canyon (CCC) and Lacaze-Duthiers Canyon (LDC), in the Gulf of Lions. Both canyons present well-developed CWC communities, but differ in terms of main hydrodynamic features and particulate fluxes (Palanques et al., 2006, 2012; Ogston et al., 2008; Sanchez-Vidal et al., 2009; Pasqual et

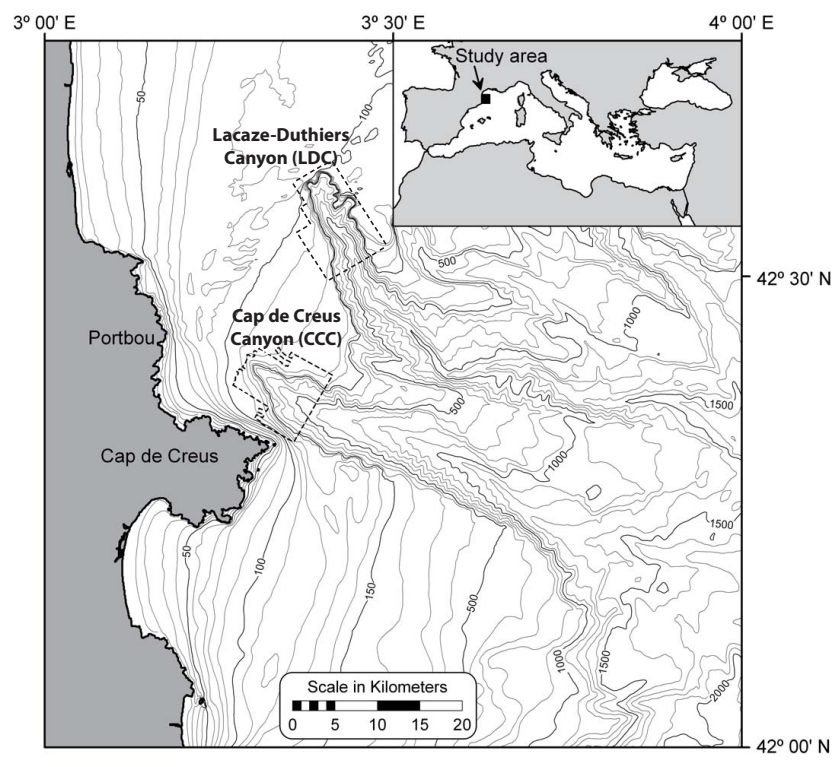

Fig. 1. Bathymetric map and location of the study areas in the western sector of the Gulf of Lions, showing the Cap de Creus Canyon (CCC) and the Lacaze-Duthiers Canyon (LDC). The areas delimited with a dashed line correspond to coverage of the multibeam bathymetry illustrated in Fig. 2.

al., 2010). The same methodology was employed in both canyons to compare: (1) the distribution of the CWC species, (2) the size structure of the coral populations, and (3) the relationships among coral colony size, depth and their position with respect to the substrate. Moreover, since protection measures will be put in place in both the studied canyons (Madurell et al., 2012; Watremez, 2012), the results of this study will also represent a before-protection assessment for monitoring programs aiming to evaluate the effectiveness of protection measures.

\section{Materials and methods}

\subsection{Research areas and target species}

The Gulf of Lions is a crescent-shaped continental margin, with a continental shelf width reaching a maximum of $\sim 70 \mathrm{~km}$. The shelf break is found at $\sim 120 \mathrm{~m}$ water depth and the slope is incised by numerous submarine canyons that extend down to the continental rise at more than $2000 \mathrm{~m}$ water depth. CCC and LDC are the westernmost submarine canyons of the Gulf of Lions margin (Fig. 1, Table 1). Highresolution multibeam bathymetry from the heads of both submarine canyons was available and has been used in this study (Fig. 2). CCC incises a narrow shelf $(<14 \mathrm{~km})$, while at LDC head region the shelf is wider $(\sim 35 \mathrm{~km})$. The CCC axis has a northwest to southeast orientation and has a single canyon head thalweg (Fig. 2a). The northern flank of the canyon displays a smooth morphology, with rounded gullies and scars; 
Table 1. Main morphological characteristics of the Cap de Creus and Lacaze-Duthiers submarine canyon heads.

\begin{tabular}{|c|c|c|c|c|c|c|c|c|c|}
\hline \multirow[t]{2}{*}{ Canyon } & \multirow[t]{2}{*}{ Max. width } & \multirow[t]{2}{*}{ Min. depth } & \multirow{2}{*}{$\begin{array}{l}\text { Min. distance } \\
\text { from the coast }\end{array}$} & \multicolumn{2}{|c|}{ Max. flank height } & \multicolumn{2}{|c|}{ Gradient range } & \multirow{2}{*}{$\begin{array}{c}\text { Average axis } \\
\text { gradient }\end{array}$} & \multirow[t]{2}{*}{ Sinuosity } \\
\hline & & & & northern flank & southern flank & northern flank & southern flank & & \\
\hline $\begin{array}{l}\text { Cap de Creus } \\
\text { Canyon (CCC) }\end{array}$ & $7.4 \mathrm{~km}$ & $128 \mathrm{~m}$ & $10 \mathrm{~km}$ & $450 \mathrm{~m}$ & $680 \mathrm{~m}$ & $6-24^{\circ}$ & $8-22^{\circ}$ & $2.0^{\circ}$ & 1.01 \\
\hline $\begin{array}{l}\text { Lacaze-Duthiers } \\
\text { Canyon (LDC) }\end{array}$ & $7.5 \mathrm{~km}$ & $125 \mathrm{~m}$ & $30 \mathrm{~km}$ & $757 \mathrm{~m}$ & $688 \mathrm{~m}$ & $10-20^{\circ}$ & $9-25^{\circ}$ & $2.3^{\circ}$ & 1.03 \\
\hline
\end{tabular}

a depositional regime prevails in this sector. In contrast, the southern flank of the canyon is characterized by the prevalence of hard rocky outcrops and steep walls, with a predominantly erosive regime (De Geest et al., 2008; Puig et al., 2008). The main reason for the contrast in morphology and sedimentary regimes between the flanks likely resides in the varying hydrodynamic regimes, with strong bottom currents and high suspended sediment loads associated with cascading events entering the canyon preferentially via the southern flank (Canals et al., 2006; Puig et al., 2008). The detailed morphological features at the head of CCC are described in Lastras et al. (2007). The LDC head displays a northnorth-west to south-south-east orientation and has three main steep branches that converge at $\sim 400 \mathrm{~m}$ water depth into a main canyon axis (Fig. 2b). The canyon is incised up to $\sim 550 \mathrm{~m}$ below the canyon rims and displays a large thalweg up to $\sim 600 \mathrm{~m}$ width, showing a prevailing depositional regime along the axis (Courp and Monaco, 1990). The southern flank shows a regular aspect until $\sim 600 \mathrm{~m}$ depth, with sub-vertical sectors, up to $25^{\circ}$ steep, and a general absence of erosive features such as landslide scars and gullies. The northern flank morphology denotes a more long-term and large-scale erosive regime, with retrograding scars reaching the edge of the flank, and two well-developed tributary valleys. Below the axis depth of $\sim 600 \mathrm{~m}$ the canyon flanks show a clear asymmetry. The southern flank is less steep and displays a more complex morphology, alternating subhorizontal terraces to steep sectors with retrograding scars and gullies. The northern flank, in contrast, is steeper and shows smooth and well-rounded landslide scars and less incised gullies. Highly energetic hydrodynamic and sedimentary processes, mainly linked to cold dense shelf water cascading events, have been monitored in both canyons during the past decade. Observations documented similar temperatures for both canyons $\left(<12^{\circ} \mathrm{C}\right)$, faster down-canyon current velocities in CCC than in LDC (80 vs $\left.60 \mathrm{~cm} \mathrm{~s}^{-1}\right)$, and higher suspended sediment concentrations (>68 vs $9.4 \mathrm{mg} \mathrm{L}^{-1}$ ) and fluxes $\left(52 \mathrm{~g} \mathrm{~m}^{-2} \mathrm{~s}^{-1}\right.$ vs $\left.5 \mathrm{~g} \mathrm{~m}^{-2} \mathrm{~s}^{-1}\right)$ in CCC than in LDC head, indicating that the $\mathrm{CCC}$ acts as a preferential conduit of dense shelf waters and associated suspended particles towards the slope region (Palanques et al., 2006, 2012; Ogston et al., 2008). The presence of CWCs in CCC and LDC has been previously documented (Pruvot, 1895; Reyss, 1964b, 1972-1973; Pérès and Piccard, 1964; Reyss and Soyer, 1965). In both canyons these communities are dom-

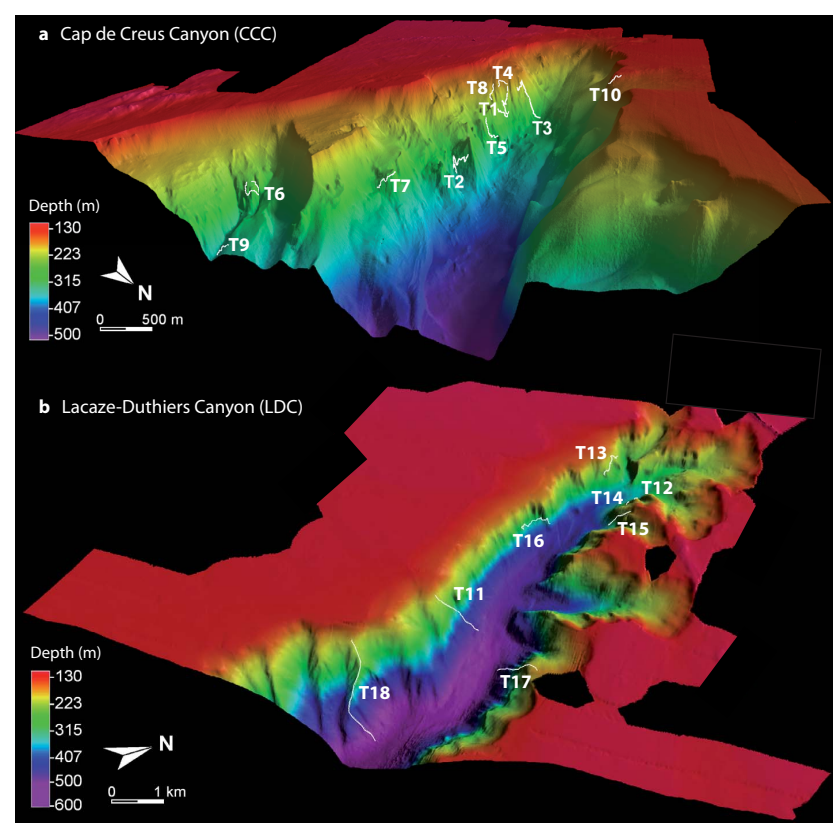

Fig. 2. Three-dimensional bathymetry illustrating the locations of the video tracks (T1 to T18) in (a) the Cap de Creus Canyon (CCC) and (b) the Lacaze-Duthiers Canyon (LDC). The CCC bathymetry was acquired by Fugro Survey, AOA Geophysics and the Universitat de Barcelona in 2004 with the hull-mounted Kongsberg Simrad EM300 $30 \mathrm{kHz}$ system, emitting 135 equidistant beams spaced every 1.0 degrees. Data were processed using Kongsberg's NEPTUNE software, and gridded with a cell size of $10 \times 10 \mathrm{~m}$. The LDC bathymetry was acquired in 1997 by IFREMER (P. I. Serge Berné) with the hull-mounted Kongsberg Simrad EM12D $13 \mathrm{kHz}$ dual system, emitting 162 beams spaced from 1.0 to 1.5 degrees. Data were processed using IFREMER's CARAIBES software, and gridded with a cell size of $20 \times 20 \mathrm{~m}$.

inated by the scleractinian coral Madrepora oculata, while the presence of Lophelia pertusa and Dendrophyllia cornigera is through isolated colonies or small patches (Orejas et al., 2009; Watremez, 2012).

M. oculata has polyps of 3-5 $\mathrm{mm}$ in diameter (Zibrowius, 1980), and forms colonies of more than $50 \mathrm{~cm}$ in height (Sanfilippo et al., 2012); it has been found at depths of 55-1950 m (Zibrowius, 1980). L. pertusa has polyps of approximately $10 \mathrm{~mm}$ in diameter, and forms colonies of more than $130 \mathrm{~cm}$ in height (Gass and Roberts, 2006), which can 
build reefs as high as $33 \mathrm{~m}$ (Mortensen et al., 2001); it has been found at depths of 40-3000 m (Zibrowius, 1980; Fosså et al., 2002; Cairns, 2007). D. cornigera has large polyps of 20-40 mm in diameter, and forms colonies more than $50 \mathrm{~cm}$ in height (Brito and Ocaña, 2004); it can be found at depths of 200-800 m (Zibrowius, 1980), but locally as shallow as $30 \mathrm{~m}$ (Castric-Fey, 1996).

\subsection{Video surveys and analyses}

Video surveys in CCC were conducted in September 2007 with the manned submersible JAGO (400 m operation depth, equipped with a 1080 horizontal lines colour video camera, and a pair of parallel laser pointers mounted $50 \mathrm{~cm}$ apart). Video surveys in LDC were conducted in November 2008 and June 2009 by the remotely operated vehicle (ROV) Super Achille $(800 \mathrm{~m}$ operation depth, equipped with a 700 horizontal lines resolution colour video camera, and a pair of parallel laser pointers mounted $6 \mathrm{~cm}$ apart). A total of 10 dives were carried out in the upper CCC head (Fig. 2a), whereas a total of 8 dives were carried out in the upper LDC head (Fig. 2b). All video material was recorded on video tapes, and transferred to hard disk prior to the analysis. The video analysis was carried out with Final Cut software (Apple). The pair of parallel laser pointers allowed demarcation of $1.5 \mathrm{~m}$-wide observation transects along the path of each dive. All live colonies of the studied coral species appearing within the $1.5 \mathrm{~m}$-wide observational transects were counted and their depth recorded, following Orejas et al. (2009) and Gori et al. (2011). Furthermore, colony size and position with respect to the substrate were recorded for $M$. oculata and $L$. pertusa. Colony size was determined by means of the two parallel laser beams and classified into four categories: small (colonies with one or a few branches), medium (colonies presenting a diameter between 10 and $20 \mathrm{~cm}$ ), large (diameter between 20 and $40 \mathrm{~cm}$ ), or very large (diameter larger than $40 \mathrm{~cm}$ ); we assume a precision of these measurements of $\pm 2 \mathrm{~cm}$. Colony position with respect to the substrate was classified into four categories according to their location and orientation: on top of rocky boulders, facing straight up $\left(0^{\circ}\right)$, perpendicular to vertical rocky walls $\left(90^{\circ}\right)$, on the edge or rocky outcrops, facing downwards $\left(135^{\circ}\right)$ and below rocky outcrops, facing downwards $\left(180^{\circ}\right)$, following Rossi et al. (2008).

\subsection{Data analysis}

All computations were performed using the $\mathrm{R}$ package (R Core Development Team, 2012). The bathymetrical distributions of the three coral species in the canyons were determined based on the recorded depth of each of the observed coral colonies. The size structures and the orientation of the colonies of M. oculata and L. pertusa were determined in all the explored sites where the species were sufficiently abundant (Fig. 2, Table 1). The size structures were analyzed in terms of descriptive statistics using the skewness of the distribution calculated with the $\mathrm{R}$ language function agostino.test, which is available in the moments library (Komsta and Novomestky, 2012). Skewness is a measure of the symmetry of a distribution using its mean; if skewness is significant, the distribution is asymmetric. Positive skewness indicates the prevalence of small size classes in the population, whereas negative skewness indicates the dominance of large size classes. The frequency of the orientation of the colonies was tested in each site by means of a chi-square test performed with the $\mathrm{R}$ language function chisq.test, with simulated $p$ value calculated by Monte Carlo simulation based on 9999 replicates when expected frequencies were $<5$. The relationship between colony size, depth and its orientation was explored by means of a correspondence analysis performed with the R language function ca, which is available in the ca library (Nenadić and Greenacre, 2007). Colony size and orientation were included as dummy (zero/one) variables, while depth was coded as a fuzzy variable using four fuzzy categories (Aşan and Greenacre, 2011; Greenacre, 2013). The definition of the four fuzzy depth categories depends on the data set being analysed. The mean depths in the four fuzzy categories (D1 to D4) are as follows: for M. oculata in CCC, $194 \mathrm{~m}, 208 \mathrm{~m}, 260 \mathrm{~m}$ and $290 \mathrm{~m}$; for M. oculata in LDC, $248 \mathrm{~m}, 264 \mathrm{~m}, 345 \mathrm{~m}$ and $428 \mathrm{~m}$; for L. pertusa in LDC, $289 \mathrm{~m}, 344 \mathrm{~m}, 495 \mathrm{~m}$ and $526 \mathrm{~m}$. This allows the continuous variable depth to be included with the other two categorical variables to explore their joint association in one ordination plot.

\section{Results}

A total of 4447 linear $m$ of sea bottom have been explored in CCC, in which a total of 790 colonies of Madrepora oculata, 16 colonies of Lophelia pertusa, and 62 colonies of Dendrophyllia cornigera were recorded in 7 of the 10 explored sites (Fig. 2, Table 2). M. oculata occurred in the canyon from 180 to $320 \mathrm{~m}$ depth (Fig. 3). The few observed colonies of $L$. pertusa were located in the same depth range as M. oculata, however most of them occurred in the deeper part of this range (Fig. 3). Colonies of D. cornigera were observed from 160 to $300 \mathrm{~m}$ depth, with a dense patch $\left(\sim 10\right.$ colonies $\left.\mathrm{m}^{-2}\right)$ entirely composed by colonies with a single polyp, located at $190 \mathrm{~m}$ depth (Fig. 3). A total of 8362 linear $\mathrm{m}$ of sea bottom have been explored in LDC, in which a total of 555 colonies of M. oculata, 97 colonies of L. pertusa, and 6 colonies of $D$. cornigera were recorded in 6 of the 8 explored sites (Fig. 2, Table 2). M. oculata occurred from 220 to $380 \mathrm{~m}$ depth, with a few deeper colonies reaching a maximum depth of $540 \mathrm{~m}$ (Fig. 3). Colonies of $L$. pertusa were mainly located from 320 to $380 \mathrm{~m}$ depth and from 500 to $540 \mathrm{~m}$ depth, with only some colonies occurring in shallower areas (Fig. 3). The few observed colonies of $D$. cornigera occurred between 220 

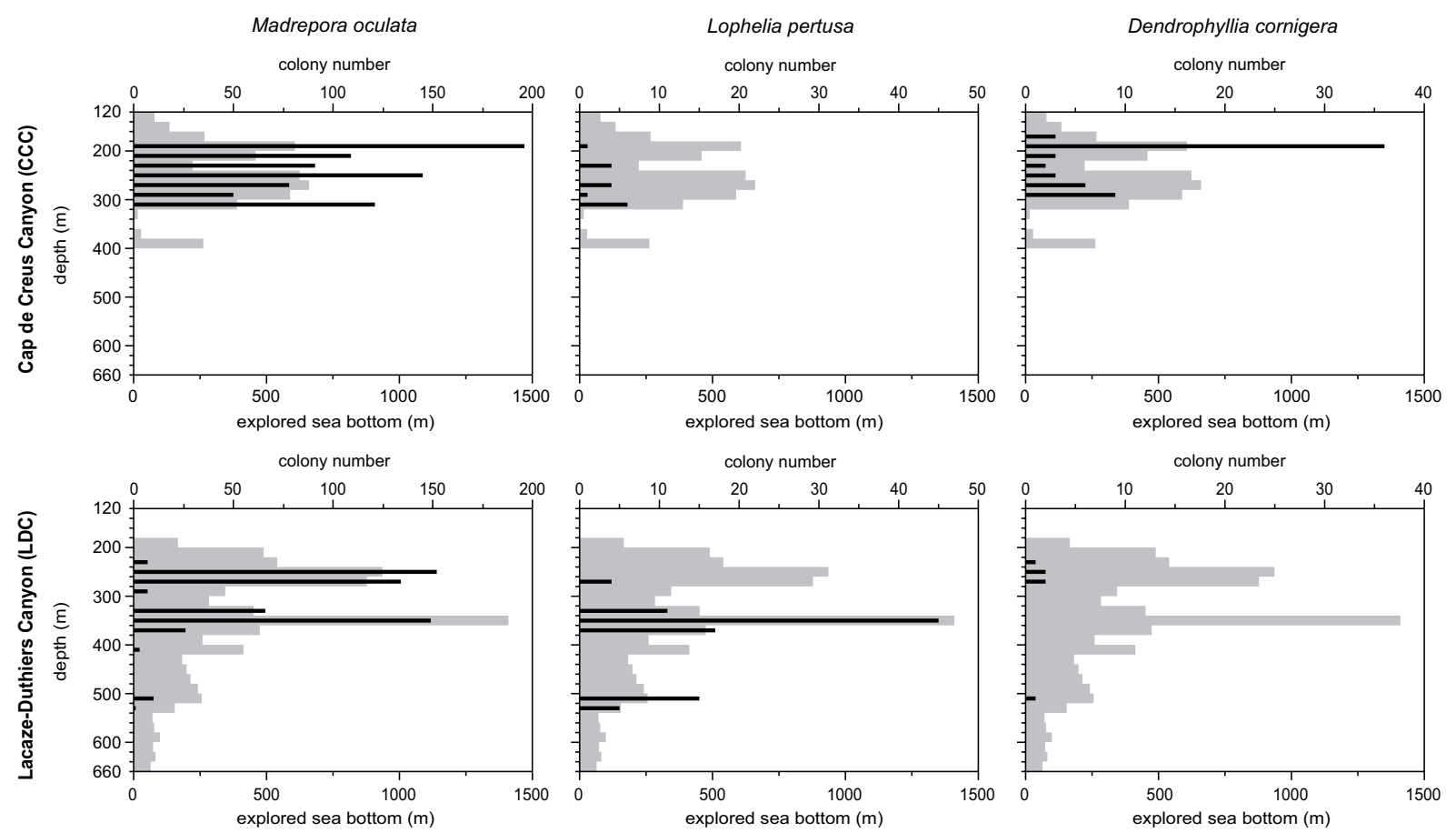

Fig. 3. Bathymetrical distribution of the Madrepora oculata, Lophelia pertusa and Dendrophyllia cornigera colonies in the Cap de Creus Canyon (CCC) and the Lacaze-Duthiers Canyon (LDC): the black line indicates the number of colonies; grey-scale histograms represent the explored sea bottom $(\mathrm{m})$ over the studied bathymetrical range.

Table 2. Location and characteristics of transects in the Cap de Creus Canyon (CCC) and Lacaze-Duthiers Canyon (LDC); number of observed colonies is indicated for each species and in each transect.

\begin{tabular}{|c|c|c|c|c|c|c|c|c|}
\hline \multirow[t]{2}{*}{ Canyon } & \multirow[t]{2}{*}{ Transect } & \multirow{2}{*}{$\begin{array}{r}\text { Length } \\
\text { (m) }\end{array}$} & \multicolumn{2}{|c|}{ Position } & \multirow{2}{*}{$\begin{array}{c}\text { Depth } \\
\text { (m, start-end) }\end{array}$} & \multirow[t]{2}{*}{ Madrepora oculata } & \multirow[t]{2}{*}{ Lophelia pertusa } & \multirow[t]{2}{*}{ Dendrophyllia cornigera } \\
\hline & & & Start & End & & & & \\
\hline Cap de Creus & $\mathrm{T} 1$ & 712 & $42^{\circ} 23.25^{\prime} \mathrm{N}, 3^{\circ} 19.00^{\prime} \mathrm{E}$ & $42^{\circ} 23.37^{\prime} \mathrm{N}, 3^{\circ} 18.83^{\prime} \mathrm{E}$ & $240-185$ & 113 & 2 & 12 \\
\hline \multirow[t]{9}{*}{ Canyon (CCC) } & $\mathrm{T} 2$ & 388 & $42^{\circ} 22.71^{\prime} \mathrm{N}, 3^{\circ} 19.75^{\prime} \mathrm{E}$ & $42^{\circ} 22.79^{\prime} \mathrm{N}, 3^{\circ} 19.73^{\prime} \mathrm{E}$ & $325-279$ & 134 & 4 & 3 \\
\hline & $\mathrm{T} 3$ & 543 & $42^{\circ} 23.63^{\prime} \mathrm{N}, 3^{\circ} 18.90^{\prime} \mathrm{E}$ & $42^{\circ} 23.47^{\prime} \mathrm{N}, 3^{\circ} 18.79^{\prime} \mathrm{E}$ & $280-191$ & 248 & 3 & 9 \\
\hline & $\mathrm{T} 4$ & 316 & $42^{\circ} 23.38^{\prime} \mathrm{N}, 3^{\circ} 18.83^{\prime} \mathrm{E}$ & $42^{\circ} 23.38^{\prime} \mathrm{N}, 3^{\circ} 18.84^{\prime} \mathrm{E}$ & $186-190$ & 118 & 0 & 22 \\
\hline & $\mathrm{T} 5$ & 475 & $42^{\circ} 23.11^{\prime} \mathrm{N}, 3^{\circ} 19.15^{\prime} \mathrm{E}$ & $42^{\circ} 23.24^{\prime} \mathrm{N}, 3^{\circ} 19.24^{\prime} \mathrm{E}$ & $230-311$ & 29 & 2 & 2 \\
\hline & T6 & 642 & $42^{\circ} 21.41^{\prime} \mathrm{N}, 3^{\circ} 20.03^{\prime} \mathrm{E}$ & $42^{\circ} 21.39^{\prime} \mathrm{N}, 3^{\circ} 20.04^{\prime} \mathrm{E}$ & $243-235$ & 20 & 1 & 4 \\
\hline & $\mathrm{T} 7$ & 343 & $42^{\circ} 22.14^{\prime} \mathrm{N}, 3^{\circ} 20.28^{\prime} \mathrm{E}$ & $42^{\circ} 22.27^{\prime} \mathrm{N}, 3^{\circ} 20.19^{\prime} \mathrm{E}$ & $293-257$ & 128 & 4 & 10 \\
\hline & $\mathrm{T} 8$ & 321 & $42^{\circ} 23.10^{\prime} \mathrm{N}, 3^{\circ} 19.14^{\prime} \mathrm{E}$ & $42^{\circ} 23.18^{\prime} \mathrm{N}, 3^{\circ} 18.87^{\prime} \mathrm{E}$ & $220-150$ & 0 & 0 & 0 \\
\hline & $\mathrm{T} 9$ & 290 & $42^{\circ} 21.98^{\prime} \mathrm{N}, 3^{\circ} 21.47^{\prime} \mathrm{E}$ & $42^{\circ} 20.97^{\prime} \mathrm{N}, 3^{\circ} 21.58^{\prime} \mathrm{E}$ & $390-376$ & 0 & 0 & 0 \\
\hline & $\mathrm{T} 10$ & 417 & $42^{\circ} 24.04^{\prime} \mathrm{N}, 3^{\circ} 19.48^{\prime} \mathrm{E}$ & $42^{\circ} 24.08^{\prime} \mathrm{N}, 3^{\circ} 19.33^{\prime} \mathrm{E}$ & $125-160$ & 0 & 0 & 0 \\
\hline Lacaze-Duthiers & $\mathrm{T} 11$ & 1124 & $42^{\circ} 32.73^{\prime} \mathrm{N}, 3^{\circ} 25.28^{\prime} \mathrm{E}$ & $42^{\circ} 32.39^{\prime} \mathrm{N}, 3^{\circ} 24.84^{\prime} \mathrm{E}$ & $537-199$ & 14 & 21 & 1 \\
\hline \multirow[t]{7}{*}{ Canyon (LDC) } & $\mathrm{T} 12$ & 152 & $42^{\circ} 34.98^{\prime} \mathrm{N}, 3^{\circ} 24.15^{\prime} \mathrm{E}$ & $42^{\circ} 34.99^{\prime} \mathrm{N}, 3^{\circ} 24.14^{\prime} \mathrm{E}$ & $276-271$ & 97 & 4 & 2 \\
\hline & $\mathrm{T} 13$ & 919 & $42^{\circ} 35.12^{\prime} \mathrm{N}, 3^{\circ} 23.26^{\prime} \mathrm{E}$ & $42^{\circ} 34.88^{\prime} \mathrm{N}, 3^{\circ} 23.48^{\prime} \mathrm{E}$ & $243-263$ & 33 & 0 & 1 \\
\hline & $\mathrm{T} 14$ & 62 & $42^{\circ} 35.08^{\prime} \mathrm{N}, 3^{\circ} 24.15^{\prime} \mathrm{E}$ & $42^{\circ} 35.08^{\prime} \mathrm{N}, 3^{\circ} 24.15^{\prime} \mathrm{E}$ & $250-253$ & 139 & 0 & 1 \\
\hline & $\mathrm{T} 15$ & 653 & $42^{\circ} 34.69^{\prime} \mathrm{N}, 3^{\circ} 24.33^{\prime} \mathrm{E}$ & $42^{\circ} 34.91^{\prime} \mathrm{N}, 3^{\circ} 24.44^{\prime} \mathrm{E}$ & $360-198$ & 36 & 3 & 1 \\
\hline & $\mathrm{T} 16$ & 1139 & $42^{\circ} 34.03^{\prime} \mathrm{N}, 3^{\circ} 23.94^{\prime} \mathrm{E}$ & $42^{\circ} 33.68^{\prime} \mathrm{N}, 3^{\circ} 23.94^{\prime} \mathrm{E}$ & $379-320$ & 236 & 69 & 0 \\
\hline & $\mathrm{T} 17$ & 1200 & $42^{\circ} 32.79^{\prime} \mathrm{N}, 3^{\circ} 26.07^{\prime} \mathrm{E}$ & $42^{\circ} 33.14^{\prime} \mathrm{N}, 3^{\circ} 26.60^{\prime} \mathrm{E}$ & $543-191$ & 0 & 0 & 0 \\
\hline & $\mathrm{T} 18$ & 3122 & $42^{\circ} 31.17^{\prime} \mathrm{N}, 3^{\circ} 26.49^{\prime} \mathrm{E}$ & $42^{\circ} 31.35^{\prime} \mathrm{N}, 3^{\circ} 25.15^{\prime} \mathrm{E}$ & $658-200$ & 0 & 0 & 0 \\
\hline
\end{tabular}

and $260 \mathrm{~m}$ depth, with some deeper colonies located between 550 and $520 \mathrm{~m}$ depth (Fig. 3).

In the 7 sites where M. oculata was documented in CCC, its populations were mainly dominated by medium and large colonies (Fig. 4). Skewness was significantly negative for two populations (T4 and T7), showing the dominance of the largest classes (Table 3). Very large colonies were observed in 3 sites and were rather abundant in one of them (T3), where they accounted for $14.5 \%$ of the colonies. Occurrence of small colonies of M. oculata was variable among sites in $\mathrm{CCC}$, and only in two populations (T2 and T6) they represented more than $20 \%$ of the colonies. On the other side, in the 6 sites where M. oculata was documented in LDC, its populations were mainly dominated by medium colonies (Fig. 4), skewness was significantly negative for one population (T14), and only one very large colony of $M$. oculata 
Table 3. Skewness of the size structures, and chi-square test on colony orientation in the studied populations of Madrepora oculata and Lophelia pertusa in the Cap de Creus Canyon (CCC) and Lacaze-Duthiers Canyon (LDC); significant $p$ values are indicated with one ( $p$ value $<0.05)$, two $(p$ value $<0.01)$, or three asterisks $(p$ value $<0.001)$.

\begin{tabular}{|c|c|c|c|c|c|c|c|c|}
\hline \multirow[t]{2}{*}{ Canyon } & \multirow[t]{2}{*}{ Species } & \multirow[t]{2}{*}{ Transect } & \multicolumn{3}{|c|}{ Size structure } & \multicolumn{3}{|c|}{ Colony orientation } \\
\hline & & & Skewness & $p$ value & & $\chi^{2}$ & $p$ value & \\
\hline Cap de Creus & Madrepora oculata & $\mathrm{T} 1$ & -0.43 & 0.2084 & & 89.94 & $<0.001$ & $* * *$ \\
\hline \multirow{6}{*}{ Canyon (CCC) } & & $\mathrm{T} 2$ & -0.04 & 0.8992 & & 205.22 & $<0.001$ & $* * *$ \\
\hline & & $\mathrm{T} 3$ & 0.07 & 0.7664 & \multirow{4}{*}{$* *$} & 104.03 & $<0.001$ & $* * *$ \\
\hline & & $\mathrm{T} 4$ & -1.07 & 0.0052 & & 84.37 & $<0.001$ & $* * *$ \\
\hline & & $\mathrm{T} 5$ & -0.18 & 0.7580 & & 15.83 & 0.0012 & $* *$ \\
\hline & & T6 & -0.06 & 0.9320 & & 23.2 & $<0.001$ & $* * *$ \\
\hline & & $\mathrm{T} 7$ & -1.32 & $<0.001$ & $* * *$ & 39.25 & $<0.001$ & $* * *$ \\
\hline Lacaze-Duthiers & Madrepora oculata & $\mathrm{T} 11$ & 0.03 & 0.9781 & \multirow{8}{*}{$*$} & 42.00 & $<0.001$ & $* * *$ \\
\hline \multirow[t]{7}{*}{ Canyon (LDC) } & & $\mathrm{T} 12$ & -0.16 & 0.6494 & & 54.22 & $<0.001$ & $* * *$ \\
\hline & & $\mathrm{T} 13$ & 0.86 & 0.1585 & & 36.21 & $<0.001$ & $* * *$ \\
\hline & & $\mathrm{T} 14$ & -0.64 & 0.0486 & & 96.02 & $<0.001$ & $* * *$ \\
\hline & & $\mathrm{T} 15$ & 0.23 & 0.6744 & & 18.44 & $<0.001$ & $* * *$ \\
\hline & & $\mathrm{T} 16$ & 0.20 & 0.4042 & & 168.78 & $<0.001$ & $* * *$ \\
\hline & Lophelia pertusa & $\mathrm{T} 11$ & -0.19 & 0.7738 & & 25.67 & $<0.001$ & $* * *$ \\
\hline & & $\mathrm{T} 16$ & 0.32 & 0.4463 & & 23.58 & $<0.001$ & $* * *$ \\
\hline
\end{tabular}

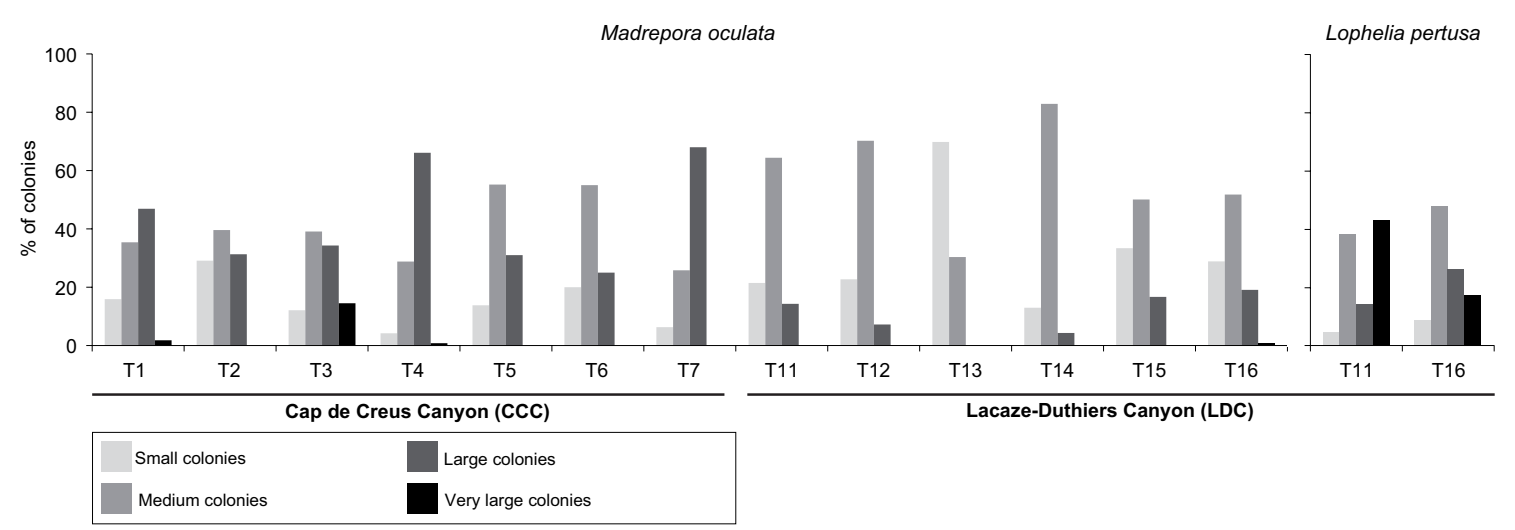

Fig. 4. Size-frequency distribution of Madrepora oculata and Lophelia pertusa populations in the Cap de Creus Canyon (CCC) and the Lacaze-Duthiers Canyon (LDC).

was observed (T16). Small colonies accounted for more than $20 \%$ of the colonies in 5 of the sites in LDC, and dominated in one of them (T13), where they accounted for $69.7 \%$ of the colonies. In the two sites where L. pertusa was abundant, its populations were dominated by medium and large or very large colonies (Fig. 4). In LDC a massive coral framework structure was observed (T16) on a vertical rocky wall with outcrops at 320-330 m depth, faced to $10-40^{\circ}$ heading, and with an estimated length of approximately $20 \mathrm{~m}$. This framework was mainly composed by live L. pertusa (Fig. 5), with presence of some $M$. oculata colonies, and was not considered in the size structure and colony orientation analyses since it was not possible to determine the number of colonies forming the framework due to the entanglement of branches from different colonies.
In both canyons and at all sites, colonies of $M$. oculata were mainly orientated at $90^{\circ}$ (Fig. 6, Table 3). In CCC the rest of the colonies were mainly orientated at $135^{\circ}$ and $0^{\circ}$, and only few colonies were orientated at $180^{\circ}$ under rocky outcrops. In LDC the rest of the colonies were mainly orientated at $135^{\circ}$, and only a small number of colonies were orientated at $180^{\circ}$ and $0^{\circ}$. Colonies of L. pertusa were primarily orientated at $90^{\circ}$, with the rest of the colonies mainly orientated at $0^{\circ}$ (Fig. 6).

The correspondence analyses performed for the $M$. oculata colonies in both canyons and L. pertusa in LDC are shown in Fig. 7. In CCC the largest size colonies of $M$. oculata were preferentially orientated at $0^{\circ}$, and at shallower depths, whereas the smallest colonies were preferentially orientated at $90^{\circ}$ and at deeper depths. In LDC the relationship 


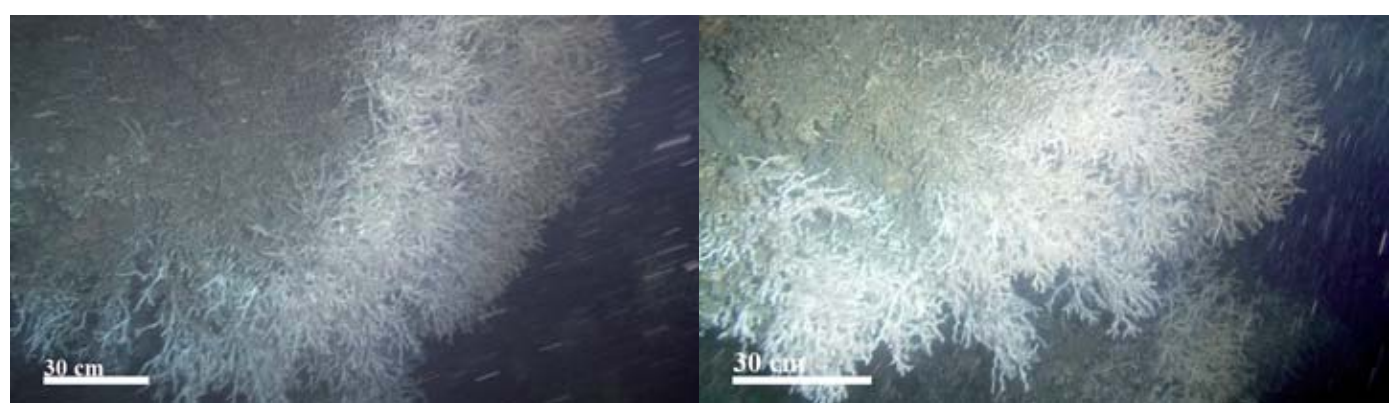

Fig. 5. Massive coral framework structure observed on a vertical rocky wall with outcrops on the southern flank of the Lacaze-Duthiers Canyon (LDC, T16) at 320-330 m depth, faced to $10-40^{\circ}$ heading, and with an estimated length of approximately $20 \mathrm{~m}$. This framework was mainly composed of live Lophelia pertusa, with presence of some Madrepora oculata colonies.

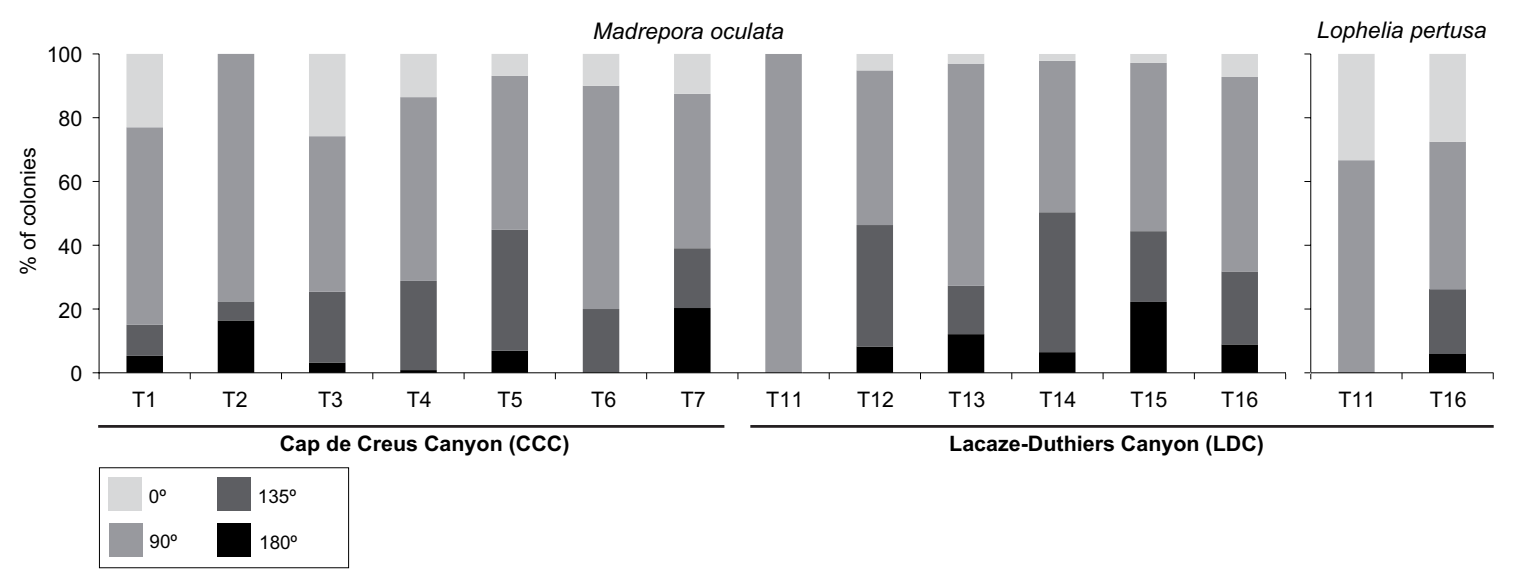

Fig. 6. Orientation of the Madrepora oculata and Lophelia pertusa colonies in the Cap de Creus Canyon (CCC) and the Lacaze-Duthiers Canyon (LDC).

between depth and size was the opposite, both for $M$. oculata and L. pertusa, with smaller colonies found in shallower depths and larger colonies at deeper depths. As far as orientation is concerned, smaller and medium colonies of $M$. oculata tended to be preferentially oriented at $180^{\circ}$ and $135^{\circ}$, while large colonies were oriented at $0^{\circ}$. These associations in LDC were similar for L. pertusa, the only difference being that large colonies tended to be preferentially oriented at $135^{\circ}$.

\section{Discussion}

In both canyons Madrepora oculata was the most abundant CWC species, while Lophelia pertusa and Dendrophyllia cornigera were present with much lower abundances. In CCC $M$. oculata was almost 45 fold more abundant than L. pertusa and 12 fold more than D. cornigera. Likewise, in LDC M. oculata was almost 10 fold more abundant than L. pertusa and 100 fold more than $D$. cornigera. This dominance of $M$. oculata has already been documented also for the central Mediterranean (Taviani et al., 2005; Freiwald et al., 2009; Vertino et al., 2010), but contrasts with the dom- inance of L. pertusa in the North Atlantic CWC communities (e.g. Mortensen et al., 1995; Rogers, 1999; Fosså et al., 2002; Roberts et al., 2009b). The factors determining these differences are still unclear, but dominance of $M$. oculata in the Mediterranean Sea could be related to its wider tolerance to environmental conditions (Wienberg et al., 2009). However, the observation of an extensive coral framework mostly composed of live L. pertusa colonies developing on a cliff in LDC (Fig. 5) demonstrates that CWC frameworks also occur in the Mediterranean Sea, even if maybe restricted to certain locations, such as the canyon flanks, where even L. pertusa can find highly suitable environmental conditions to develop. The L. pertusa framework documented in LDC was very similar to the one recently observed on cliffs in the Whittard Canyon in the Bay of Biscay (Huvenne et al., 2011), although the extent of the L. pertusa framework in LDC is 2 orders of magnitude smaller than in the Whittard Canyon (Huvenne et al., 2011). Moreover, L. pertusa frameworks up to $5 \mathrm{~m}$ in extent were also observed in the Santa Maria di Leuca CWC province, in the central Mediterranean (Vertino, personal communication, 2013). 

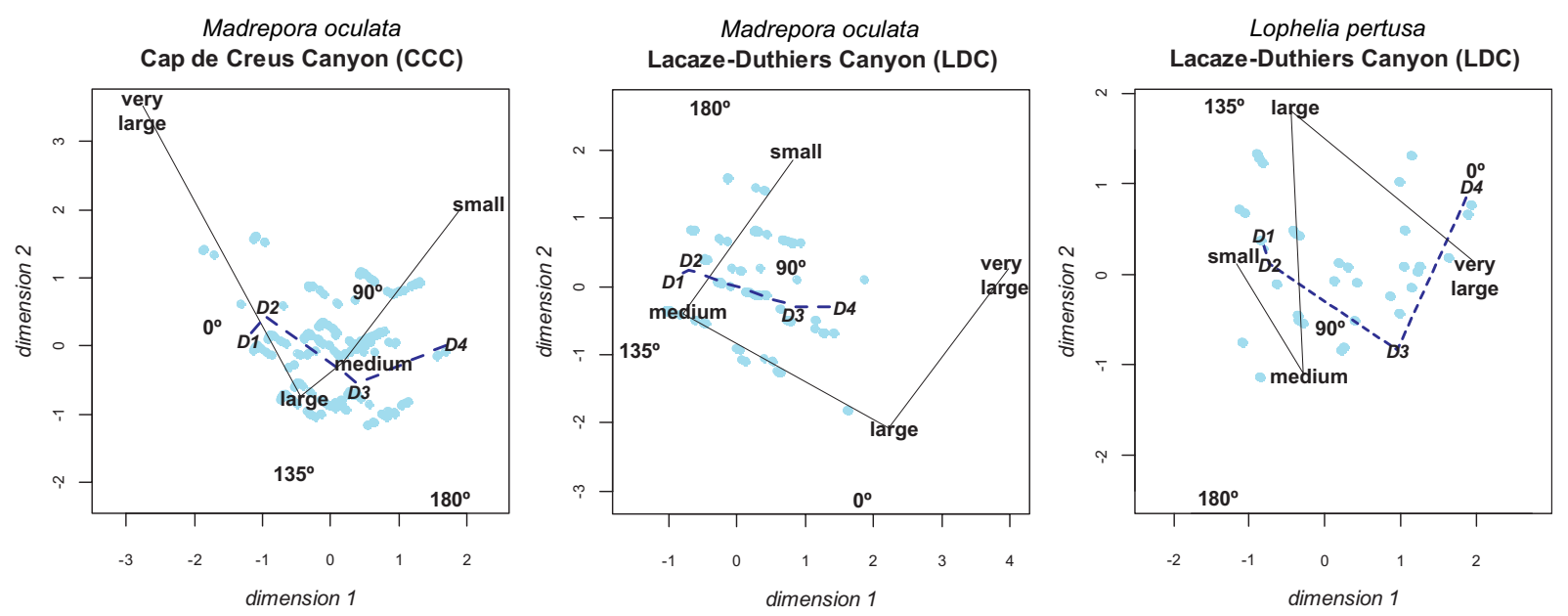

Fig. 7. Correspondence analysis showing the relationship between Madrepora oculata and Lophelia pertusa colony size, colony orientation and depth in the Cap de Creus Canyon (CCC) and the Lacaze-Duthiers Canyon (LDC). Samples are shown by dots; the ordinal categories of size and depth (increasing from D1 to D4) are connected by solid and dashed lines, respectively.

Our results showed different bathymetrical distribution patterns of the three species, which are all present from shallower depths $(\sim 180 \mathrm{~m}$ depth $)$ in CCC than in LDC $(\sim 220 \mathrm{~m}$ depth). A wide tolerance to environmental conditions could also explain the shallower distribution of M. oculata in both canyons, with high abundances mainly between 180 and $360 \mathrm{~m}$ depth. Although, its colonies were larger in the shallower zone of this depth range in the CCC $(\sim 200 \mathrm{~m}$ depth), while they were larger in the deeper zone of this range in the LDC ( $\sim 340 \mathrm{~m}$ depth). Conversely, L. pertusa colonies were larger and more abundant in deeper zones. Temperature constraints might explain the deeper distribution of L. pertusa, which is considered to be exposed to its maximal thermal tolerance in the Mediterranean Sea (Freiwald et al., 2009; Maier et al., 2012). The shallower distribution of $D$. cornigera among CWC species was already documented in the Mediterranean Sea (Reyss, 1972-1973) as well as in the North Atlantic (Álvarez-Claudio, 1994; Castric-Fey, 1996; Brito and Ocaña, 2004; Reveillaud et al., 2008). These differences observed in the bathymetric distribution patterns of the three CWC species studied might also explain the different abundances of $L$. pertusa between canyons, which is biased due to the lack of investigations below $400 \mathrm{~m}$ depth in CCC. Hence, it would be worthwhile to explore the deeper areas of CCC in order to verify if a higher abundance of $L$. pertusa exists deeper in the canyon as it occurs in LDC. The bathymetrical distribution patterns of CWC in the studied canyons occur out of the optimal potential water density envelope, as described by Dullo et al. (2008), which has been also observed for CWC in the Whittard Canyon (Huvenne et al., 2011) and in the Gulf of Mexico (Davies et al., 2010). Since the optimal density envelope has been proposed to increase, through supporting the formation of intermediate nepheloid layers, food availability for $L$. pertusa colonies in the north- east Atlantic (Dullo et al., 2008), the downslope transport processes that characterize submarine canyons could explain the presence of CWC out of this density envelope (Huvenne et al., 2011).

In both canyons, $M$. oculata and $L$. pertusa populations were dominated by medium- and large-sized colonies. This size structure is considered as the result of past pulses in recruitment (Grigg, 1977; Lasker, 1991), and has commonly been documented in deep-sea gorgonians (Mortensen and Buhl-Mortensen, 2005; Watanabe et al., 2009), as well as in temperate and tropical gorgonian and scleractinian species (Edmunds, 2000; Harmelin and Garrabou, 2005; Linares et al., 2008). In some of these species it has been shown that several years of extremely low recruitment rates alternate with sporadic high recruitment peaks (Yoshioka, 1996; Hughes et al., 1999; Edmunds, 2000; Garrabou and Harmelin, 2002; Bramanti et al., 2005). However, long-lived species have been shown to be buffered against such fluctuations in recruitment (Garrabou and Harmelin, 2002; Linares et al., 2007; Santangelo et al., 2007; Bramanti et al., 2009), while the survival of large and high reproductive colonies is the key factor for population persistence (Gotelli, 1991; Lasker, 1991; Linares et al., 2007). Although there is a lack of information on CWC reproductive ecology in Mediterranean Sea, the observed abundance of small colonies indicates active recruitment in both canyons. Based on the growth rates obtained in aquaria incubations, the small-sized colonies observed in this study might be 5-6 yr old (Orejas et al., 2008, 2011).

The preferential orientations $\left(90^{\circ}\right.$ and $\left.135^{\circ}\right)$ of $M$. oculata and $L$. pertusa colonies in both canyons are probably related to the main currents as well as to the sediment transported by them. These orientations of corals could represent a compromise between protection from the sediment, and exposure to 
the water flow to ensure feeding. Thus, the large amounts of sediments transported through the canyons (Heussner et al., 2006; Palanques et al., 2006; Canals et al., 2009) may prevent locations at $0^{\circ}$ orientation (i.e. upright position), which is the most common orientation in the north-east Atlantic CWC populations, where sedimentation levels are very low (Mortensen et al., 2001). A $90^{\circ}$ orientation is also frequent for the Mediterranean red coral (Corallium rubrum) colonies in deep sublittoral (50-80 m) areas (Rossi et al., 2008), while a dominance of upright $\left(0^{\circ}\right)$ orientated colonies has been documented in CWC areas, where corals settle preferentially on the top of features or on the up-current flank of elevations (Genin et al., 1986; Mortensen et al., 2001; Reed et al., 2006; Freiwald et al., 2009; Vertino et al., 2010). In LDC the frequency of colonies with upright orientation was slightly higher than in CCC, which might be related to the lower sediment flux observed in LDC compared to the CCC (Palanques et al., 2006, 2012; Pasqual et al., 2010).

Overall, no clear differences were observed in the abundance of $\mathrm{CWC}$, as well as in their population structure in CCC and LDC, despite the main differences between canyons in terms of hydrodynamic conditions and especially fluxes of particulate matter (Palanques et al., 2006, 2012; Pasqual et al., 2010). This suggests that the particle flux in LDC, although lower than in CCC, is probably large enough to ensure suitable environmental conditions for the development of mature CWC populations. On the other hand, the lower sedimentation rates documented in LDC could act as a positive factor for the development of the CWC communities, which are more affected in $\mathrm{CCC}$ by the very high sedimentation rates (Palanques et al., 2006). In a similar way, also the weaker currents documented in LDC could promote coral feeding, since slow flows $\left(2.5 \mathrm{~cm} \mathrm{~s}^{-1}\right)$ were shown to maximize zooplankton capture rates in L. pertusa (Purser et al., 2010). The higher frequency of lost long-line fishing gear found in CCC with respect to LDC (Orejas et al., 2009; Watremez, 2012) suggest that this canyon could be more affected by anthropogenic impacts. Long-line fishing gear has been frequently observed entangled in coral colonies, and this fisheries impact has already been recognized as a cause of coral mortality (Hourigan et al., 2007; Orejas et al., 2009). Since protection measurements are planned for both canyon heads in the near future (Madurell et al., 2012; Watremez, 2012), a future comparison of CWC distribution patterns and population structure with the results of this study will allow assessment of the recovery rates of CWC populations and evaluation of the effectiveness of the protection measures.

Acknowledgements. The authors acknowledge Fugro Survey, AOA Geophysics and the Universitat de Barcelona for providing the Cap de Creus Canyon multibeam bathymetry, and Serge Berné and IFREMER for providing the Lacaze-Duthiers Canyon multibeam bathymetry. We are indebted to the crews of the RV García del Cid and the Minibex, the JAGO team (J. Schauer and K. Hissmann) from IFM-GEOMAR (Kiel, Germany) and the scientific team onboard the Minibex during the MEDSEACAN sampling cruises; without their help it would not have been possible to carry out the field work. This work was funded by the European project LIFE + INDEMARES "Inventario y designación de la red natura 2000 en áreas marinas del estado español" (LIFE07/NAT/E/000732), and HERMIONE (Grant Agreement Number 226354), the Spanish project DEEP CORAL (CTM2005-07756-C02-02/MAR), the Acciones Complementarias (CTM2005-24174-E, CTM2006- 27063-E/MAR, CTM200728758-E/MAR), and the Agence des Aires Marines Protégées (AAMP) for organizing and financing the MEDSEACAN cruises. A. G., C. O., T. M. and C. L. I. were supported by I3P and JAEDOC contract of the Consejo Superior de Investigaciones Cientificas.

Edited by: A. Freiwald

\section{References}

Álvarez-Claudio, C.: Deep-water Scleractinia (Cnidaria Anthozoa) from southern Biscay Bay, Cah. Biol. Marr., 35, 461-469, 1994.

Aşan, Z. and Greenacre, M.: Biplots of fuzzy coded data, Fuzzy Set. Syst., 183, 57-71, 2011.

Baillon, S., Hamel, J. F., Wareham, V. E., and Mercier, A.: Deep cold-water corals as nurseries for fish larvae, Front. Ecol. Environ., 10, 351-356, 2012.

Bramanti, L., Magagnini, G., De Maio, L., and Santangelo, G.: Recruitment, early survival and growth of the Mediterranean red coral Corallium rubrum (L, 1758), a 4-year study, J. Exp. Mar. Biol. Ecol., 314, 69-78, 2005.

Bramanti, L., Santangelo, G., and Iannelli, M.: Mathematical modelling for conservation and management of gorgonians corals: young and olds, could they coexist?, Ecol. Model., 20, 28512856, 2009.

Brito, A. and Ocaña, O.: Corales de las islas Canarias, in: Antozoos con esqueleto de los fondos litorales y profundos, edited by: Lemus, F., La Laguna, 2004

Buhl-Mortensen, L., Vanreusel, A., Gooday, A. J., Levin, L. A., Priede, I. G., Buhl-Mortensen, P., Gheerardyn, H., King, N. J., and Raes, M.: Biological structures as a source of habitat heterogeneity and biodiversity on the deep ocean margins, Mar. Ecol.Evol. Persp., 31, 21-50, 2010.

Cairns, S. D.: Deep-water corals: an overview with special reference to diversity and distribution of deep-water scleractinian corals, B Mar. Sci., 81, 311-322, 2007.

Canals, M., Puig, P., Durrieu de Madron, X., Heussner, S., Palanques, A., and Fabrés, J.: Flushing submarine canyons, Nature, 444, 354-357, 2006.

Canals, M., Danovaro, R., Heussner, S., Lykousis, V., Puig, P., Trincardi, F., Calafat, A., Durrieu de Madron, X., Palanques, A., and Sánchez-Vidal, A.: Cascades in Mediterranean submarine grand canyons, Oceanography, 22, 26-43, 2009.

Castric-Fey, A.: Le Scléractiniaire Dendrophyllia cornigera en eau peu profonde, à Ouessant (Bretagna, Atlantique NE) en l'absence de barrière thermique, Oceanol. Acta, 19, 665-671, 1996.

Costello, M. J., McCrea, M., Freiwald, A., Lundälv, T., Jonsson, L., Bett, B. J., van Weering, T. C. E., de Haas, H., Roberts, J. M., and Allen, D.: Role of cold-water Lophelia pertusa coral reefs as fish habitat in the NE Atlantic, in: Cold-water Corals and 
Ecosystems, edited by: Freiwald, A. and Roberts, J. M., Springer, Berlin, 771-805, 2005.

Courp, T. and Monaco, A.: Sediment dispersal and accumulation on the continental margin of the Gulf of Lions: sedimentary budget, Cont. Shelf Res., 10, 1063-1087, 1990.

Davies, A. J., Wisshak, M. O., James, C., and Roberts, J. M.: Predicting suitable habitat for the cold-water coral Lophelia pertusa (Scleractinia), Deep-Sea Res. I, 55, 1048-1062, 2008.

Davies, A. J., Duineveld, G. C. A., Lavaleye M. S. S., Bergman, M. J. N, van Haren H., and Roberts J. M.: Downwelling and deepwater bottom currents as food supply mechanisms to the coldwater coral Lophelia pertusa (Scleractinia) at the Mingulay Reef complex, Limnol. Oceanogr., 54, 620-629, 2009.

Davies, A. J., Duineveld, G. C. A., van Weering, T. C. E., Mienis, F., Quattrini, A. M., Seim, H. E., Bana, J. M., and Ross, S. W.: Short-term environmental variability in cold-water coral habitat at Viosca Knoll, Gulf of Mexico, Deep-Sea Res. I, 57, 199-212, 2010.

De Leo, F. C., Smith, C. R., Rowden, A. A., Bowden, D. A., and Clark, M. R.: Submarine canyons: hotspots of benthic biomass and productivity in the deep sea, P. Roy. Soc. Lond. B Bio., 277, 2783-2792, 2010.

DeGeest, A. L., Mullenbach, B. L., Puig, P., Nittrouer, C. A., Drexler, T. M., Durrieu de Madron, X., and Orage, D. L.: Sediment accumulation in the western Gulf of Lions, France: the role of Cap de Creus canyon in linking shelf and slope sediment dispersal systems, Cont. Shelf Res., 28, 2031-2047, 2008.

D’Onghia, G., Maiorano, P., Sion, L., Giove, A., Capezzuto, F., Carlucci, R., and Tursi, A.: Effects of deep-water coral banks on the abundance and size structure of the megafauna in the Mediterranean Sea, Deep-Sea Res. II, 57, 397-411, 2010.

Dullo, W. C., Flögel, S., and Rüggeberg, A.: Cold-water coral growth in relation to the hydrography of the Celtic and Nordic European continental margin, Mar. Ecol.-Prog. Ser., 371, 165176, 2008.

Edmunds, P. J.: Patterns in the distribution of juvenile corals and coral reef community structure in St. John, US Virgin Islands, Mar. Ecol.-Prog. Ser., 202, 113-124, 2000.

Fosså, J. H., Mortensen, P. B., and Furevik D. M.: The deepwater coral Lophelia pertusa in Norwegian waters: distribution and fishery impacts, Hydrobiologia, 471, 1-12, 2002.

Frederiksen, R., Jensen, A., and Westerberg, H.: The distribution of the scleractinian coral Lophelia pertusa around the Faroe Islands and the relation to internal tidal mixing, Sarsia, 77, 157$171,1992$.

Freiwald, A., Beuck, L., Rüggeberg, A., Taviani, M., and Hebbeln, D.: The white coral community in the Central Mediterranean Sea revealed by ROV surveys, Oceanography, 22, 58-74, 2009.

Garrabou, J. and Harmelin, J. G.: A 20-year study on lifehistory traits of a harvested long-lived temperate coral in the NW Mediterranean: insights into conservation and management needs, J. Anim. Ecol., 71, 966-978, 2002.

Gass, S. E. and Roberts, J. M.: The occurrence of the cold-water coral Lophelia pertusa (Scleractinia) on oil and gas platforms in the North Sea: colony growth, recruitment and environmental controls on distribution, Mar. Pollut. Bull., 52, 549-559, 2006.

Genin, A., Dayton, P. K., Lonsdale, P., and Spiess, F.: Corals on seamount peaks provide evidence of current acceleration over deep-sea topography, Nature, 322, 59-61, 1986.
Gili, J. M., Pagès, F., Bouillon, J., Palanques, A., Puig, P., Heussner, S., Calafat, A., Canals, M., and Monaco, A.: A multidisciplinary approach to the understanding of hydromedusan populations inhabiting Mediterranean submarine canyons, Deep-Sea Res. I, 47, 1513-1533, 2000.

Gori, A., Rossi, S., Berganzo, E., Pretus, J. L., Dale, M. R. T., and Gili, J. M.: Spatial distribution patterns of the gorgonians Eunicella singularis, Paramuricea clavata and Leptogorgia sarmentosa (Cape of Creus, Northwestern Mediterranean Sea), Mar. Biol., 158, 143-158, 2011.

Gotelli, N. J.: Demographic models for Leptogorgia virgulata, a shallow-water gorgonian, Ecology, 72, 457-467, 1991.

Greenacre, M. J.: Fuzzy coding in constrained ordinations, Ecology, in press, doi:10.1890/12-0981.1, 2013

Grigg, R. W.: Age structure of a longevous coral: a relative index of habitat suitability and stability, Am. Nat., 109, 647-657, 1975.

Grigg, R. W.: Population dynamics of two gorgonian corals, Ecology, 58, 278-290, 1977.

Harmelin, J. G. and Garrabou, J.: Suivi d'une population de Paramuricea clavata (Risso, 1826) (Cnidaria, Octocorallia, Gorgonacea) dans le parc national de Port-Cros (Méditerranée, France): comparaison des états 1992 et 2004 sur le site de la Galère, Sci. Rep. Port-Cros Natl. Park, 21, 175-191, 2005.

Harris, P. T. and Whiteway, T.: Global distribution of large submarine canyons: Geomorphic differences between active and passive continental margins, Mar. Geol., 285, 69-86, 2011.

Henry, L. A. and Roberts, J. M.: Biodiversity and ecological composition of macrobenthos on cold-water coral mounds and adjacent off-mound habitat in the bathyal Porcupine Seabight, NE Atlantic, Deep-Sea Res. I, 54, 654-672, 2007.

Heussner, S., Durrieu de Madron, X., Calafat, A., Canals, M., Carbonne, J., Delsaut, N., and Saragoni, G.: Spatial and temporal variability of downward particle fluxes on a continental slope: Lessons from an 8-yr experiment in the Gulf of Lions (NW Mediterranean), Mar. Geol., 234, 63-92, 2006.

Hourigan, T. F., Lumsden, S. E., Dorr, G., Bruckner, A. W., Brooke, S., and Stone, R. P.: Deep coral ecosystems of the United States: introduction and national overview, in: The state of deep coral ecosystems of the United States, edited by: Lumsden, S. E., Hourigan, T. F., Bruckner, A. W., and Dorr, G., NOAA Tech Memo CRCP-3, Silver Spring, MD, 1-64, 2007.

Hughes, T. P., Baird, A. H., Dinsdale, E. A., Moltschaniwskyj, N. A., Pratchett, M. S., Tanner, J. E., and Willis, B. L.: Patterns of recruitment and abundance of corals along the Great Barrier Reef, Nature, 397, 59-63, 1999.

Husebø, A., Nottestad, L., Fosså, J. H., Furevik, D. M., and Jorgensen, S. B.: Distribution and abundance of fish in deep-sea coral habitats, Hydrobiologia, 471, 91-99, 2002.

Huvenne, V. A. I., Tyler, P. A., Masson, D. G., Fisher, E. H., Hauton, C., Hühnerbach, V., Le Bas, T. P., and Wolff, G. A.: A picture on the wall: innovative mapping reveals coldwater coral refuge in submarine canyon, PLoS ONE, 6, e28755, doi:10.1371/journal.pone.0028755, 2011.

Kenyon, N. H., Akhmetzhanov, A. M., Wheeler, A. J., van Weering, T. C. E., de Haas, H., and Ivanov, M. K.: Giant carbonate mud mounds in the southern Rockall Trough, Mar. Geol., 195, 5-30, 2003.

Komsta, L. and Novomestky, F.: Moments: Moments, cumulants, skewness, kurtosis and related tests, $\mathrm{R}$ package 
version 0.12 , http://cran.r-project.org/web/packages/moments/ index.html, (last access: 26 February 2013), 2012.

Lasker, H. R.: Population growth of a gorgonian coral: equilibrium and non-equilibrium sensitivity to changes in life history variables, Oecologia, 86, 503-509, 1991.

Lastras, G., Canals, M., Urgeles, R., Amblas, D., Ivanov, M., Droz, L., Dennielou, B., Fabrés, J., Schoolmeester, T., Akhmetzhanov, A., and Orange, D. L.: A walk down the Cap de Creus canyon, northwestern Mediterranean Sea: Recent processes inferred from morphology and sediment bedforms, Mar. Geol., 246, 176-192, 2007.

Levin, L. A. and Sibuet, M.: Understanding continental margin biodiversity: a new imperative, Annual Review of Marine Science, 4, 79-112, 2012.

Linares, C., Doak, D. F., Coma, R., Díaz, D., and Zabala, M.: Life history and viability of a long-lived marine invertebrate: the octocoral Paramuricea clavata, Ecology, 88, 918-928, 2007.

Linares, C., Coma, R., Garrabou, J., Díaz, D., and Zabala, M.: Size distribution, density and disturbance in two Mediterranean gorgonians: Paramuricea clavata and Eunicella singularis, J. Appl. Ecol., 45, 688-699, 2008.

Lo Iacono, C., Orejas, C., Gori, A., Gili, J. M., Requena, S., Puig, P., and Ribó, M: Habitats of the Cap de Creus continental shelf and Cap de Creus canyon, northwestern Mediterranean, in: Seafloor geomorphology as benthic habitat, edited by: Harris, P. T. and Baker, E. K., Elsevier, London, 457-469, 2012.

Madurell, T., Orejas, C., Requena, S., Gori, A., Purroy, A., Lo Iacono, C., Sabatés, A., Dominguez-Carrió, C., and Gili, J. M.: The benthic communities of the Cap de Creus Canyon, in: Mediterranean submarine canyons: Ecology and governance, edited by: Würtz, M., IUCN, Switzerland and Spain, 123-132, 2012.

Maier, C., Watremez, P., Taviani, M., Weinbauer, M. G., and Gattuso, J. P.: Calcification rates and the effect of ocean acidification on Mediterranean cold-water corals, P. Roy. Soc. Lond. B Bio., 279, 1716-1723, 2012.

Mortensen, P. B. and Buhl-Mortensen, L.: Morphology and growth of the deep-water gorgonians Primnoa resedaeformis and Paragorgia arborea, Mar. Biol., 147, 775-788, 2005.

Mortensen, P. B., Hovland, M., Brattegard, T., and Farestveit, R.: Deep water bioherms of the scleractinian coral Lophelia pertusa (L.) at $64^{\circ} \mathrm{N}$ on the Norwegian shelf: structure and associated megafauna, Sarsia, 80, 145-158, 1995.

Mortensen, P. B., Hovland, T., Fossa, J. H., and Furevik, D. M.: Distribution, abundance and size of Lophelia pertusa coral reefs in mid-Norway in relation to seabed characteristics, J. Mar. Biol. Assoc. UK, 81, 581-597, 2001.

Nenadić, O. and Greenacre, M.: Correspondence analysis in R, with two- and three-dimensional graphics: The ca package, Journal of Statistical Software, 20, http://www.jstatsoft.org/v20/i03/, 2007.

Nittrouer, C. A. and Wright, L. D.: Transport of particles across continental shelves, Rev. Geophys., 32, 85-113, 1994.

Ogston, A. S., Drexler, T. M., and Puig, P.: Sediment delivery, resuspension, and transport in two contrasting canyon environments in the southwest Gulf of Lions, Cont. Shelf Res., 28, 2000-2016, 2008.

Orejas, C., Gori, A., and Gili, J. M.: Growth rate of live Lophelia pertusa and Madrepora oculata from the Mediterranean Sea maintained in aquaria, Coral Reefs, 27, 255, 2008.
Orejas, C., Gori, A., Lo Iacono, C., Puig, P., and Gili, J. M.: Coldwater corals in the Cap de Creus canyon, northwestern Mediterranean: spatial distribution, density and anthropogenic impact, Mar. Ecol.-Prog. Ser., 397, 37-51, 2009.

Orejas, C., Ferrier-Pagès, C., Reynaud, S., Gori, A., Beraud, E., Tsounis, G., Allemand, D., and Gili, J. M.: Long-term growth rate measurements of four Mediterranean cold water coral species (Madrepora oculata, Lophelia pertusa, Desmophyllum cristagalli and Dendrophyllia cornigera) maintained in aquaria, Mar. Ecol.-Prog. Ser., 429, 57-65, 2011.

Palanques, A., Durrieu de Madron, X., Puig, P., Fabres, J., Guillén, J., Calafat, A., Canals, M., Heussner, S., and Bonnin, J.: Suspended sediment fluxes and transport processes in the Gulf of Lions submarine canyons, The role of storms and dense water cascading, Mar. Geol., 234, 43-61, 2006.

Palanques, A., Guillén, J., Puig, P., and Durrieu de Madron, X.: Storm-driven shelf-to-canyon suspended sediment transport at the southwestern end of the Gulf of Lions, Mar. Geol., 28, 19471956, 2008.

Palanques, A., Puig, P., Durrieu de Madron, X., Sanchez-Vidal, A., Pasqual, C., Martín, J., Calafat, A., Heusner, S., and Canals, M.: Sediment transport to the deep canyons and open-slope of the western Gulf of Lions during the 2006 intense cascading and open-sea convection period, Prog. Oceanogr., 106, 1-15, 2012.

Pasqual, C., Sanchez-Vidal, A., Zúñiga, D., Calafat, A., Canals, M., Durrieu de Madron, X., Puig, P., Heussner, S., Palanques, A., and Delsaut, N.: Flux and composition of settling particles across the continental margin of the Gulf of Lion: the role of dense shelf water cascading, Biogeosciences, 7, 217-231, doi:10.5194/bg-7217-2010, 2010.

Pérès, J. M. and Picard, J.: Nouveau manuel de bionomie benthique de la mer Mediterranée, Extrait du Recueil des travaux de la Station Marine d'Endoume, 31, 5-137, 1964.

Pruvot, G.: Coup d'oeil sur la distribution générale des invertébrés dans la région de Banyuls (golfe du Lion), Arch. Zool. Exp. Gen., 3, 629-658, 1895.

Puig, P., Ogston, A. S., Mullenbach, B. L., Nittrouer, C. A., and Sternberg, R. W.: Shelf-to-canyon sediment-transport processes on the Eel continental margin (northern California), Mar. Geol., 193, 129-149, 2003.

Puig, P., Palanques, A., Orange, D. L., Lastras, G., and Canals, M.: Dense shelf water cascades and sedimentary furrow formation in the Cap de Creus Canyon, north-western Mediterranean Sea, Cont. Shelf Res., 28, 2017-2030, 2008.

Purser, A., Larsson, A. I., Thomsen, L., and van Oevelen, D.: The influence of flow velocity and food concentration on Lophelia pertusa (Scleractinia) zooplankton capture rates. J. Exp. Mar. Biol. Ecol., 395, 55-62, 2010.

R Core Development Team.: R: A language and environment for statistical computing, http://www.R-project.org, last access: 28 November 2012.

Reed, J. K., Weaver, D. C., and Pomponi, S. A.: Habitat and fauna of deep-water Lophelia pertusa coral reefs off the southeastern US: Blake Plateau, Straits of Florida, and Gulf of Mexico, B. Mar. Sci., 78, 343-375, 2006.

Reveillaud, J., Freiwald, A., Van Rooij, D., Le Guilloux, E., Altuna, A., Foubert, A., Vanreusel, A., Olu-Le Roy, K., and Henriet, J. P.: The distribution of scleractinian corals in the Bay of Biscay, NE Atlantic. Facies, 54, 317-331, 2008. 
Reyss, D. and Soyer, J.: Etude de deux vallées sous-marines de la mer Catalane (compte rendu de plongées en soucoupe plongeante SP 300), Bull. Inst. Océanogr., 65, 1-27, 1965.

Reyss, D.: Contribution à l'étude du rech Lacaze-Duthiers, vallée sous-marine des côtes du Roussillon, Vie Milieu, 15, 1-146, $1964 \mathrm{a}$

Reyss, D.: Observations faites en soucoupe plongeante dans deux vallées sous-marines de la mer Catalane: le rech du Cap et le rech Lacaze-Duthiers, Bull. Inst. Océanogr., 63, 1-8, 1964b.

Reyss, D.: Les canyons sous-marins de la mer catalane le Rech du Cap et le Rech Lacaze-Duthiers IV - étude synécologique des peuplements de macrofaune benthique, Vie Milieu, 23, 101-142, 1972-73.

Roberts, J. M., Davies, A. J., Henry, L. A., Dodds, L. A., Duineveld, G. C. A., Lavaleye, M. S. S., Maier, C., van Soest, R. W. M., Bergman, M. J. N., Hühnerbach, V., Huvenne, V. A. I., Sinclair, D. J., Watmough, T., Long, D., Green, S. L., and van Haren, H.: Mingulay reef complex: an interdisciplinary study of cold-water coral habitat, hydrography and biodiversity, Mar. Ecol.-Prog. Ser., 397, 139-151, 2009a

Roberts, J. M., Wheeler, A. J., Freiwald, A., and Cairns, S. (Eds.): Cold-water corals: the biology and geology of deep-sea coral habitats, Cambridge University Press, England, 2009b.

Rogers, A. D.: The biology of Lophelia pertusa (Linnaeus 1758) and other deep-water reef-forming corals and impacts from human activities, Int. Rev. Hydrobiol., 84, 315-406, 1999.

Ross, S. W. and Quattrini, A. M.: The fish fauna associated with deep coral banks off the southeastern United States, Deep-Sea Res. I, 54, 975-1007, 2007.

Rossi, S., Tsounis, G., Orejas, C., Padrón, T., Gili, J. M., Bramanti, L., Teixidó, N., and Gutt, J.: Survey of deep-dwelling red coral (Corallium rubrum) populations at Cap de Creus (NW Mediterranean), Mar. Biol., 154, 533-545, 2008.

Sanchez-Vidal, A., Pasqual, C., Kerhervé, P., Heussner, S., Calafat, A., Palanques, A., Durrieu de Madron, X., Canals, M., and Puig, P.: Across margin export of organic matter by cascading events traced by stable isotopes, northwestern Mediterranean Sea, Limnol. Oceanogr., 54, 1488-1500, 2009.

Sanfilippo, R., Vertino, A., Rosso, A., Beuck, L., Freiwald, A., and Taviani, M.: Serpula aggregates and their role in deepsea coral communities in the southern Adriatic Sea, Facies, doi:10.1007/s10347-012-0356-7, 2012.

Santangelo G., Bramanti L., and Iannelli M.: Population dynamics and conservation biology of the over-exploited Mediterranean Red coral, J. Theor. Biol., 244, 416-423, 2007.
Taviani, M., Remia, A., Corselli, C., Freiwald, A., Malinverno, E., Mastrototaro, F., Savini, A., and Tursi, A.: First geo-marine survey of living cold-water Lophelia reefs in the Ionian Sea (Mediterranean basin), Facies, 50, 409-417, 2005.

Thiem, O., Ravagnan, E., Fosså, J. H., and Berntsen, J.: Food supply mechanisms for cold-water corals along a continental shelf edge, J. Marine Syst., 60, 207-219, 2006.

Valiela, I.: Marine ecological processes, Springer, USA, 1995.

Vertino, A., Savini, A., Rosso, A., Di Geronimo, I., Mastrototaro, F., Sanfilippo, R., Gay, G., and Etiope, G.: Benthic habitat characterization and distribution from two representative sites of the deepwater SML Coral Province (Mediterranean), Deep-Sea Res. II, 57, 380-396, 2010.

Vetter, E. W. and Dayton, P. K.: Macrofaunal communities within and adjacent to a detritus-rich submarine canyon system, DeepSea Res. II, 45, 25-54, 1998.

Walsh, J. J.: Importance of continental margins in the marine biogeochemical cycling of carbon and nitrogen, Nature, 350, 53-55, 1991.

Watanabe, A., Metaxas, A., Sameoto, J., and Lawton, P.: Patterns in abundance and size of two deep-water gorgonian octocorals, in relation to depth and substrate features off Nova Scotia, DeepSea Res. II, 56, 2235-2248, 2009.

Watremez, P.: Canyon heads in the French Mediterranean Overview of results from the MEDSEACAN and CORSEACAN campaigns (2008-2010), in: Mediterranean submarine canyons: Ecology and governance, edited by: Würtz, M., IUCN, Switzerland and Spain, 105-112, 2012.

Wienberg, C., Hebbeln, D., Fink, H. G., Mienis, F., Dorschel, B., Vertino, A., López Correa, M., and Freiwald, A.: Scleractinian cold-water corals in the Gulf of Cádiz - First clues about their spatial and temporal distribution, Deep-Sea Res. I, 56, 18731893, 2009.

Würtz, M.: Submarine canyons and their role in the Mediterranean ecosystem, in: Mediterranean submarine canyons: Ecology and governance, edited by: Würtz, M., IUCN, Switzerland and Spain, 11-26, 2012.

Yoshioka, P. M.: Variable recruitment and its effects on the population and community structure of shallow-water gorgonians, B. Mar. Sci., 59, 433-443, 1996.

Zibrowius, H.: Les scléractiniaires de la Méditerranée et de l'Atlantique nord-oriental, Mem. Inst. Oceanogr. (Monaco), 11, 1-284, 1980. 